УДК 378:37.09:364-2

DOI 10.11603/me.2414-5998.2019.3.10658

О. М. Филипюк

ORCID 0000-0002-1907-3408

T. М. Нестерук

ORCID 0000-0002-0447-9026

О. В. Штрімайтіс

ORCID 0000-0002-1305-2251

Р. О. Сабадишин

КЗВО «Рівненська медична академія», Рівне

\title{
«АПТЕКА ЩАСТЯ» - БЛАГОДІЙНИЙ ЗАХІД ПРОФЕСІЙНОГО ТА МОРАЛЬНО-ЕТИЧНОГО СПРЯМУВАННЯ СТУДЕНТА-ФАРМАЦЕВТА
}

\author{
O. M. Fylypiuk, T. M. Nesteruk, O. V. Shtrimaitis, R. O. Sabadyshyn \\ Municipal Institution of Higher Education "Rivne Medical Academy” Rivne Regional Council \\ "PHARMACY OF HAPPINESS" - A CHARITY EVENT WITH THE \\ PROFESSIONAL AND MORAL-ETHICAL DIRECTION BY THE STUDENT \\ PHARMACIST
}

\begin{abstract}
Анотація. У статті проаналізовано продуктивність роботи професійно-зорієнтованого благодійного заходу «АПТЕКА ЩАСТЯ» для формування професійної компетентності студентів спеціальності «Фармація».

Розробили методологію та принцип роботи «АПТЕКИ ЩАСТЯ» як професійно-зорієнтованої структури. Задекларували асортимент та анотації до «чудодійних» ліків. Залучили студентство до формування асортименту, пакування «чарівних пігулок», а пізніше і до їх реалізації. Вартість «цікавинок» не обмежувалася, всі кошти за реалізовані препарати збирали у спеціальні скриньки та були передані з благодійною метою.

«АПТЕКА ЩАСТЯ» - благодійний захід професійно-зорієнтованого спрямування. Має на меті сформувати стійкі моральні якості майбутнього фармацевтичного працівника: людяність, доброту, милосердя, відповідальність, порядність та доброчинність. Тому повномасштабне залучення студентів до проведення подібних виховних заходів формує соціально активні та творчі особистості, які поєднують у собі високі моральні й етичні принципи та професійну компетентність.
\end{abstract}

Ключові слова: аптека щастя; професійна компетентність; професійно-зорієнтована виховна робота; благодійний захід.

Abstract. The article analyzes the performance of the professional-oriented charity event "PHARMACY OF HAPPINESS" for the formation of the professional competence of students with the specialty "Pharmacy".

The methodology and principle of the "PHARMACY OF HAPPINESS" was developed as a professionally-oriented structure. The assortment and annotations for "miraculous" drugs were announced. Students were attracted to the formation of assortment, packaging of "magic pills" and later to their realization. The cost of "interesting things" was not limited, all the funds for the realized drugs were collected in special boxes and were donated for charitable purposes.

"PHARMACY OF HAPPINESS" is a charity event of a professional orientation. With the goal of forming the steady moral qualities of the future pharmaceutical worker: humanity, kindness, mercy, responsibility, decency and charity. Therefore, full-scale involvement of students in conducting such educational activities forms socially active and creative individuals, who combine high moral and ethical principles and professional competence.

Key words: pharmacy of happiness; professional competence; professionally oriented educational work; charity event.

Вступ. Стрімкий розвиток науково-технічного прогресу призводить до дегуманізації суспільства, що негативно відображається на суспільних відносинах, рівень людяності у яких значно знижується. Тому питання моральності людських відносин, особливо за сучасних умов в Україні, є актуальним і потребує вдосконалення та пошуків нових шляхів її відродження. Феномен благодійності виступає одним із таких можливих механізмів [1].

Успішна практична діяльність фахівця фармацевтичної індустрії визначається рівнем сформованості професійних компетенцій. Найбільш ефектив- 
ним засобом професійно-особистісного розвитку висококваліфікованих фахівців під час підготовки до професійної діяльності у вищих навчальних закладах є компетентнісний підхід, у межах якого процес навчання розуміється як комплексна діяльність, націлена на формування у студентів набору загальнонавчальних, загальнокультурних та професійних компетенцій [2].

Виховання як основна складова в освітньому процесі передбачає гуманізацію взаємин між усіма його учасниками, повагу до особистості, розуміння її запитів, інтересів, гідності, довіру до неї, сприяє вихованню гуманної особистості - щирої, людяної, доброзичливої, толерантної, милосердної [3].

Мета статті - аналіз продуктивності роботи професійно-зорієнтованого благодійного заходу «АПТЕКА ЩАСТЯ» для формування професійної компетентності студентів спеціальності «Фармація».

Завданнями дослідження були:

- розробка методології та принципу роботи «АПТЕКИ ЩАСТЯ» як професійно-зорієнтованої структури;

- створення асортименту аптеки та формування інструкцій до застосування товарів аптеки;

- безпосереднє проведення благодійних заходів;

- аналіз отриманих результатів.

Теоретична частина. Професійно-виховний захід полягає у формуванні чудодійного асортименту «АПТЕКИ ЩАСТЯ» та реалізації чарівних ліків з метою зібрати благодійні кошти для людей, чиє здоров’я і життя залежать від якісної дороговартісної медичної допомоги.

Розроблений асортимент дозволяє придбати ліки, які не знайдуться в жодному аптечному закладі. Для «цілющих» пігулок і таблеток ми підібрали різноманітні цукерки, льодяники, драже та інші кондитерські вироби, привабливі як за зовнішнім виглядом, так і за смаковими якостями. Унікальні ліки можуть «подарувати» щастя, радість і сміх, допоможуть позбутися смутку і депресії. Знайдуться й цікаві «цілющості» для лінивих і забудьків; для тих, хто не може втримати язика за зубами, чи хто має легку залежність від соціальних мереж. Багатьох зацікавила група «серцевих препаратів», що допомагає в душевних справах. А для студентів $є$ особливі ліки, що допоможуть «здати» сесію чи відмінити заняття, на яке не дуже хочеться йти. Загалом, були представлені «цікавинки» для всіх.

Декларуємо асортимент «АПТЕКИ ЩАСТЯ» та анотації до ліків. Кожен препарат супроводжується жартівливою інструкцією та спонукає відвідува- ча аптеки усміхнутися і з великим задоволенням придбати його собі, рідним, друзям та долучитися до благодійної справи.

«Антиборзин» - використовувати тоді, коли гострих кутів не вдається обійти «полюбовно». Рекомендовано порахувати до десяти перед тим, як випити.

«Антитупін» - не гальмуй, просто не гальмуй. Показання: знижена мозкова діяльність, відсутність думок, тимчасова втрата адекватного мислення. Дія настає швидко, але ефект триває не більше 15 хв.

«Антитусін» - просто побудь вдома (користується популярністю у батьків підлітків).

«Внетінесидин» - для інтернет-залежних. Передозування. Симптоми: головний біль, млявість, тремтіння рук, різка відраза до гаджетів.

«Губозакотин» - допомагає «повернутися в реальність».

«Жабонедушин» - препарат допомагає звільнитися від нав’ язливих думок, які пригнічують настрій. Седативна дія проявляється повільно, але досить стабільно. Завдяки вмісту алкалоїдів - «ропухину» i «квакотину» препарат чинить слабку спазмолітичну дію. Ліки зменшуються збудливість ЦНС і допомагають легше «пережити» чиїсь досягнення.

«Згадайдележин» - показання: легка форма забудькуватості. Допомагає знайти ключі, телефон, лекційний зошит, пульт від телевізора тощо. Не зловживати! Організм швидко звикає. Умови зберігання: зберігати в оригінальній упаковці на видному місці.

«Креативін» - показання: гостра нестача яскравих моментів у житті. Особливості застосування: під час застосування препарату необхідно утримуватися від вживання алкогольних напоїв.

«Паривідмінил» - «чудодійний» препарат, після прийому якого заняття через невідому причину переноситься чи взагалі відміняється. Вживати 3 обережністю. При систематичному вживанні викликає залежність. Протипоказаний препарат для вчителів і викладачів.

«Підзадпендалін» - показання: для лінивих; застосовувати лише за призначенням, дія настає відразу в момент введення.

«Подарин» - таблетки від жадібності. Побічна дія: озноб і надзвичайно сильне бажання зробити подарунок. Протипоказання: не вживати на порожній гаманець. Користується особливою популярністю в жінок.

«Половинкошукатин» - допомагає при гострій «серцевій недостатності» знайти свою другу половинку. Протипоказання: не рекомендовано вжи- 
вати одруженим, тому що наслідки дії препарату можуть бути непередбачувані.

«Попихун» - підвищує інтерес до роботи (навчання). Виписується на вимогу керівництва (куратора).

«Похрустин»-лікувальні антистресові сухарики. Після 2-3 хв енергійного «хрустіння» почуття тривоги різко знижується. Передозування небезпечне розвиваються симптоми хвороби «море по коліна».

«Похудин» - унікальний препарат, розроблений для жінок, які мріють мати струнку талію і не відмовляти собі у смаколиках 24 год на добу.

«Привітальна пілюля» - коли треба привітати керівника (вчителя), а в голові - «пусто».

«Прямостон»- на основі екстракту перстачу прямостоячого - для мужчин будь-якого віку.

«Рукизплечейвідростан» - допомагає боротися 3 синдромом «руки з одного місця». Тривалість лікування не менше одного місяця. При застосуванні препарату слід утримуватися від роботи з потенційно небезпечними механізмами.

«Серотонін» - гормон щастя. Для тих, хто мріє «світитися зсередини». Знімає напругу, впливає на сон і апетит, формує почуття задоволення і підвищує настрій.

«Сесіюздаван» - допомагає в нелегкий час екзаменаційної сесії, підвищує опірність організму до великого об’єму інформації, зменшує тривалість нічного сну і розвиває тимчасову «здатність до списування». Особливо корисно приймати при написанні шпаргалок.

«Сміхонагонин» - якщо Ваші анекдоти не смішні. Рекомендовано для тих, хто мріє стати «душею компанії».

«Стопхандрин» - зупиняє безпідставну нудьгу і меланхолію.

«Таблетка «Студентська» - допомагає подолати різке відчуття голоду і побороти дрімоту під час заняття. Також відчутно прискорює наближення кінця навчального дня. У рекомендованих дозах легко позбавляє «навчальних мук».

«Таблетки «Щастя»- антидепресант нового покоління. Виготовлений на основі розробок провідних позитивних і життєрадісних фармакологів світу, м’яко і ніжно діє на психіку людини. Підвищує опірність організму до смутку, тривоги, депресій. У кожній таблетці міститься необхідна кількість активних речовин, які відповідають за позитивний емоційний стан людини. До складу таблеток входять «веселятори» і «хіхотатори», які сприяють підтримуванню рівня радості в межах верхньої поділки «шкали» щастя.
«Шкарпеткошукатин» - спеціально для хлопців та чоловіків.

«Язикозазубамитриман»-призначений для осіб, які спочатку говорять, а потім думають. Підходить як для жінок, так і для чоловіків. Показання: тяга до розмов та пліток.

До формування асортименту та пакування «чарівних» ліків були залучені студенти-фармацевти, які в подальшому і були працівниками «АПТЕКИЩАСТЯ». Фактично вперше здійснюючи фармацевтичну опіку, студенти могли проявити себе у ролі фармацевтів і з жартівливого боку намагалися допомогти подолати різні «недуги». Вартість «чарівних» ліків не обмежувалася, всі кошти за реалізовані препарати збирали у спеціальні скриньки та були передані з благодійною метою.

По закінченні заходу студенти були сповнені масою приємних вражень та емоцій. Їхні серця переповнювала радість за здійснену доброчинну справу та щира віра в те, що в майбутньому вони обов'язково стануть кваліфікованими та високоморальними фахівцями.

Вперше захід відбувся у вересні 2017 р. до Дня фармацевтичного працівника. Та нині вже успішно себе зарекомендував як благодійний захід у м. Рівному: у серпні 2018 р. в парку культури та відпочинку ім. Т. Г. Шевченка під час «Медичного пікніка»; навесні 2019 р. в Рівненському обласному академічному музично-драматичному театpi пройшло декілька благодійних вистав, під час яких активно функціонувала «АПТЕКА ЩАСТЯ». Авторами ідеї є викладачі кафедри хіміко-фармацевтичних дисциплін К3ВО «Рівненська медична академія» О. М. Филипюк та Т. М. Нестерук.

Висновки та перспективи подальших досліджень. «АПТЕКА ЩАСТЯ» - благодійний захід професійно-зорієнтованого спрямування. Має на меті сформувати стійкі моральні якості майбутнього фармацевтичного працівника: людяність, доброту, милосердя, відповідальність, порядність та доброчинність. Тому повномасштабне залучення студентів до проведення подібних виховних заходів формує соціально активні та творчі особистості, які поєднують у собі високі моральні й етичні принципи та професійну компетентність.

Перспективи подальших досліджень вбачаємо у збільшенні асортименту «АПТЕКИ ЩАСТЯ», плануємо розширювати місця проведення даного благодійного заходу, а також активно займаємося розробкою нових виховних заходів благодійного спрямування. 


\section{Список літератури}

1. Житник М. М. Благодійність у соціально-філософській ретроспективі та перспективі / М. М. Житник // Вісник НТУУ «КПІ». Філософія. Психологія. Педагогіка. - 2015. - Вип. 2. - С. 43-49.

2. Нікогосян Л. Р. Формування готовності майбутніх фахівців фармацевтичних спеціальностей до професійної діяльності в процесі фахової підготовки / Л. Р. Ні-

\section{References}

1. Zhytnyk, M.M. (2015). Blahodiinist u sotsialnofilosofskyi retrospektyvi ta perspektyvi [Charity in sociophilosophical retrospect and prospect]. Visnyk NTUU “KPI”. Filosofiia. Psykholohiia. Pedahohika - Bulletin of NTUU “KPI”. Philosophy. Psychology. Pedagogy, 2, 43-49 [in Ukrainian].

2. Nikohosian, L.R. (2016). Formuvannia hotovnosti maibutnikh fakhivtsiv farmatsevtychnykh spetsialnostei do когосян // Педагогічні науки. - 2016. - Вип. LXXIV, т. 2. - С. 146-150.

3. Тернопільська В. І. Довідник з виховної роботи зі студентами / В. I. Тернопільська, Т. В. Коломієць, I. О. Піонтківська. - Тернопіль : Навчальна книга - Богдан, 2014. - 264 с.

profesiinoi diialnosti [Formation of readiness of the future specialists pharmaceutical specialties to professional activity in the process of training]. Pedahohichni nauky-Pedagogical Sciences, LXXIV (2), 146-150 [in Ukrainian].

3. Ternopilska, V.I., Kolomiets, T.V., \& Piontkivska, I.O. (2014). Dovidnyk z vykhovnoi roboty zi studentamy [Handbook on educational work with students]. Ternopil: Navchalna knyha: Bohdan [in Ukrainian]. 